\title{
The American Hospital in Moscow: A Lesson in International Cooperation, 1917-23
}

\author{
SUSAN GRANT* \\ Liverpool John Moores University, John Foster Building, 98 Mount Pleasant, \\ Liverpool L3 5UZ, UK
}

\begin{abstract}
In its examination of American Medical Aid to Russia, this article shows how the best of intentions can have the potential to go horribly awry. It argues that the competing binary forces of international collaboration and goodwill versus political tensions and uncertainty combined to create an environment wherein actors and agents inhabited an ever changing and unpredictable international stage. Could American philanthropic organisations and individuals overcome political volatility, financial restrictions and ideological barriers? Just what would it take to establish an American hospital in Moscow, the Bolshevik seat of power? The attempt to establish the hospital proved to be an exercise in patience, persistence and prudence (although not always in equal measure). This article shows that international cooperation, while undoubtedly complicated, was certainly possible. The flow of information, materiel and personnel between the United States, Germany and Russia proved that good intentions, trust and a will to help others were valued. The history of American Medical Aid to Russia also demonstrates that the Quaker role of facilitator and interlocutor was vital in establishing a relationship of trust between Soviet Russia and the United States. This article discusses the difficulties that philanthropic organisations faced when navigating the choppy international waters of the early 1920s and highlights the rewards of successfully doing this. It argues that basic human relationships and trust were just as, if not sometimes more, important than ideology in determining the tenor of early US-Soviet relations.
\end{abstract}

Keywords: Medical, Hospital, Soviet Russia, Quakers, America, International

* Email address for correspondence: susangrant@campus.ie

I wish to thank Dr Laura Kelly, University of Strathclyde, Dr Seth Bernstein (Higher School of Economics, Moscow), Professor Susan Solomon (University of Toronto), and the journal's two anonymous reviewers for reading and commenting on this paper. Many thanks are also due to Don Davis of the American Friends Service Committee archive, Philadelphia. Funding for this research was generously provided by an Irish Research Council/Marie Curie postdoctoral fellowship. Any mistakes or omissions are my own. 


\section{Introduction $^{1}$}

During the First World War and after the Bolshevik Revolution, a number of international relief agencies operated in Russia, seeking to alleviate the famine and refugee catastrophe. These included the American Friends Service Committee (AFSC or Quakers), American Red Cross, the American Relief Administration, the Save the Children Fund, the American Jewish Joint Distribution Commission, the Rockefeller philanthropies and American Medical Aid to Russia. During the war, the Anglo-Russian hospital (1915-18), staffed by both Russian and British personnel, stood as a symbol of cooperation between British philanthropists and Russia. ${ }^{2}$ The Bolshevik authorities welcomed foreign assistance with People's Commissar for Foreign Affairs, Georgy V. Chicherin, noting that AFSC activities in Moscow since 1917 'deserved nothing but appreciation' and the cooperation with Russian institutions they enjoyed spoke sufficiently to the Russian attitude towards their work. ${ }^{3}$ Chicherin cautioned, however, that this did not mean that the doors of Soviet Russia would be opened wide for 'all kinds of foreign relief societies and organisations' that wanted to do relief work there, and warned that the 'overwhelming majority' of these were 'unfriendly' and wanted to use their activities for anti-Soviet propaganda. Indeed, after the worst of the famine was over in 1921, most foreign charities considered their duty done and left Russia. As Julia Irwin has noted in her work on the American Red Cross, sending aid to Europe was much less popular by $1920 .{ }^{4}$ For Bolshevik Russia, humanitarian assistance was even less popular.

The Quakers, or AFSC, was considered the most politically neutral relief organisation and enjoyed the best relationship with the new Russian authorities. ${ }^{5}$ The other major relief organisation was the American Relief Administration (ARA), established in 1919 with Herbert Hoover as Director. Hoover was also United States Secretary of Commerce at this time, a powerful position that bestowed upon the ARA additional political and economic clout, as evidenced by the 1921 Riga Agreement granting the ARA sole right to distribute in Russia. The prior arrangement between the AFSC and the Russian government meant that they could remain independent of the ARA, much to the chagrin of Hoover. ${ }^{6}$ Consequently, other relief organisations - such as American Medical Aid to Russia - approached the AFSC for assistance with distribution of supplies. The AFSC was

\footnotetext{
${ }^{1}$ Note on transliteration: I have adhered to Library of Congress transliteration style but spelling errors or variations of proper names, for example, Michael and Mikhail, Mikhailovsky and Michailovsky or Kotsva, Catsza, etc. remain the same as in original texts.

2 See Michael Harmer, The Forgotten Hospital (Chichester: Springwood, 1982).

${ }^{3}$ American Friends Service Committee Archives. General Administration: Foreign Service; Russia (hereafter, AFSC, FS, Russia), People's Commissar for Foreign Affairs (Chicherin) to Arthur Watts, 14 April 1921.

${ }^{4}$ Julia Irwin, Making the World Safe: The American Red Cross and a Nation's Humanitarian Awakening (New York: Oxford University Press, 2013), 144.

5 The Quakers signed an agreement with the Soviet government guaranteeing political and religious neutrality; the fact that Quakers remained in Russia until 1931 was testament to their 'good behaviour' and the trust placed in their personnel.

${ }^{6}$ For more on the repercussions of Riga and the exchange of opinion on the matter between the AFSC and Hoover (himself a Quaker), see Swarthmore College archives, RG 5 Thomas, Series 6 Ref material, AFSC, 1922. The collection contains letters between Hoover and Rufus M. Jones, and between Wilbur Thomas and Hoover, written in January 1922. It should also be noted that O.D. Kameneva, head of the Central Commission for Struggle against the Consequences of the Famine (Posledgol, October 1922-August 1923), waged a campaign against the ARA. See Margaret Akers Trott, 'Soviet Medicine and Western Medical Charity, 1917-27' (PhD Dissertation, University of Virginia, 1996) and 'Passing through the Eye of a Needle: American Philanthropy and Soviet Medical Research in the 1920s', in William H. Schneider, ed., Rockefeller Philanthropy and Modern Biomedicine: International Initiatives from World War I to the Cold War (Indiana: Bloomington, 2002). See also
} 
willing to do this because it was committed to helping Russia in any way it could. However, it drew the line at undertaking anything that was vaguely political because this ran counter to its agreement with the Russian government. As David McFadden has observed, AFSC Chairman Rufus Jones 'envisioned a Quaker role in US-Russian reconciliation'. 7 Fraught US-Russian relations after the Bolshevik revolution precipitated a 'Red Scare' in the US, and thus enshrouded relief efforts in an extra layer of political sensitivity. The balancing act of keeping the Russian and American authorities happy was something the AFSC had to master, and was not always easy to achieve. International diplomacy could be shaped and compromised by internal domestic relationships, such as those between the American philanthropists involved in Soviet Russia. This is shown in Bertrand Patenaude's work on the ARA during the Russian famine years, in which he argues that the strained relationship between Hoover and the AFSC always threatened to become 'an issue'. ${ }^{8}$ The case of American Medical Aid to Russia (hereafter AMAR) confirms this, and reinforces the argument that problematic relations within the world of American philanthropy could prove to have far-reaching consequences for international relations.

This article takes as its focus the efforts of AMAR to establish an American hospital in Moscow. Humanitarian aid and problems in US-Soviet relations have received considerable scholarly attention in recent years, with studies focusing on the ARC and ARA. By unearthing the history of AMAR, this paper shows that a small-scale operation with the simple objective of improving the medical situation in Russia had a big impact on US-Soviet relations. In telling the story of the American hospital in Moscow, this paper strips away the layers of bureaucracy and ideology to reveal the fundamental importance of power, control and trust. While the function of American Medical Aid to Russia has been examined in McFadden and Gorfinkel's Constructive Spirit and Margaret Trott's work on Soviet medical research in the 1920s, there is nonetheless a great deal of intrigue that merits further exploration. ${ }^{9}$ McFadden and Gorfinkel's excellent work is a general overview of Quaker involvement in Russia; there is one chapter that deals with medical contribution, but it does not draw attention to the AMAR venture. In her article, Margaret Trott recognises the importance of the AMAR affair, but summarises it as part of wider US-Soviet medical interactions in the 1920s. This article sheds light on the depth and quantity of correspondence, the delicate political situation and how the different personalities at play all contributed to a fascinating history of international and inter-organisational cooperation after the First World War. Of course, this merely underlines the much more pressing concern of AMAR - to equip and supply a hospital in Moscow to serve a population so desperately in need of medical assistance. The case of AMAR reminds us that philanthropic work not only made a significant contribution towards improving medical and social conditions, but also helped forge relationships across national and ideological boundaries. Most of my source material emanates from the AFSC archives in Philadelphia and the State Archive of the Russian Federation in Moscow. The record of correspondence between those in the United States, Soviet Russia, and Germany reveals the sheer effort and paperwork required to establish an American hospital

Benjamin M. Weissman, Herbert Hoover and Famine Relief to Soviet Russia: 1921-23 (Stanford, CA: Hoover Institution Press, 1974).

${ }^{7}$ McFadden, Constructive Spirit, 30.

${ }^{8}$ Bertrand M. Patenaude, The Big Show in Bololand: The American Relief Expedition to Soviet Russia in the Famine of 1921 (Stanford, CA: Stanford University Press, 2002), 141.

${ }^{9}$ David McFadden and Claire Gorfinkel, Constructive Spirit: Quakers in Revolutionary Russia (Pasadena, CA: Intentional Productions, 2004), 109-132. 
in Moscow. The article begins by exploring the origins of AMAR and its relationship with Quakers, before assessing the political machinations and financial troubles that plagued the organisation.

For those readers unfamiliar with Soviet history, it is worth noting that relations between the West and Russia at this time were generally tense. Trade links were established after the First World War, and it seemed that good liaisons forged here would facilitate political progress. During the first three years after the revolution, economics certainly helped to keep a 'chaotic situation fluid'. ${ }^{10}$ Still, 'economic diplomacy', as David McFadden has termed it, did not produce the desired effect in politics. ${ }^{11}$ Another opportunity presented itself, however, in the form of 'cultural diplomacy' through medical cooperation, as explored by Susan Solomon. ${ }^{12}$ In the 1920 s, healthcare was one of the few areas where Soviet Russia could engage and negotiate. However, broader political tensions often infringed on this sphere too.

The ideological differences between the US and Soviet Russia, especially the latter's desire to promote socialism internationally, led to frequent friction between the two states. The trade blockade (in place between 1918 and 1920) and White intervention in the Russian Civil War (with inter alia US, British, French and Japanese support for the anti-Bolshevik forces, 1918-21) meant that the Russian government was unsurprisingly suspicious of the American famine relief effort in 1921. Such suspicion was, indeed, not unfounded, for Herbert Hoover did not place much trust in the Russian state either, and the ARA and American Red Cross were often viewed with hostility and scepticism by the Bolshevik government. This became apparent during the strained Riga negotiations during the summer of 1921, convened to outline the conditions of famine support. The talks highlighted the serious tensions in US-Soviet relations, with the ARA and Russia both seeking complete autonomy. In the end, Hoover (through his representative in Riga) agreed to concede some Russian control. ${ }^{13}$ After the agreement, American support was publicly acknowledged and appreciated in Russia. ${ }^{14}$ Hoover had succeeded in the immense diplomatic task of pleasing both the Bolsheviks and the American public. ${ }^{15}$

Political scientist Mark L. Haas argues that Soviet-US cooperation might just have been an example of 'short-run pragmatism' to advance more long-term ideological objectives. ${ }^{16}$ Stephen M. Walt claims that Soviet advances in peaceful diplomatic relations were undermined by its frequent attempts to export revolution. ${ }^{17}$ The example of the American hospital in Moscow shows that cooperation in healthcare and philanthropy

10 David W. McFadden, Alternative Paths. Soviets and Americans, 1917-20 (New York, Oxford: Oxford University Press, 1993), 339.

${ }^{11}$ Ibid., 121, 124, and 267 passim.

12 For just one example, see Susan Solomon, Doing Medicine Together: Germany and Russia Between the Wars (Toronto: University of Toronto Press, 2006). See also Michael David-Fox, Showcasing the Great Experiment: Cultural Diplomacy and Western Visitors to the Soviet Union, 1921-41 (New York: Oxford University Press, 2012).

13 Although, according to a British correspondent, it was a 'victory' for the Americans as the Russians gave way on the most salient points. See Weissman, 65. For more on the tense relationship between the ARA and AFSC, see Patenaude, The Big Show in Bololand, 141, 604.

14 Adam B. Ulam, Expansion and Coexistence. Soviet Foreign Policy 1917-73 (New York: Praeger, 1976), 148.

15 Michael Barnett, Empire of Humanity: A History of Humanitarianism (Ithaca and London: Cornell University Press, 2011), 87.

${ }^{16}$ Mark L. Haas, 'Soviet Grand Strategy in the Interwar Years: Ideology as Realpolitik', 293, in The Challenge of Grand Strategy: The Great Powers and the Broken Balance between the Wars, Jeffrey W. Taliaferro, Norrin M. Ripsman, and Stephen E. Lobell (eds) (Cambridge: Cambridge University Press, 2012), 279-307.

${ }^{17}$ Stephen M. Walt, Revolution and War (Ithaca and London: Cornell University Press, 1996), 195. 
placed humanitarian needs before ideological goals. For those involved, but especially the Commissariat of Public Health, the stakes were high and the immediate need for such a hospital was profound. Realising this need meant liaising with Americans, and so the effort to fund and establish the hospital proved to be a huge test in trusting the 'ideological foe'.

\section{'A Permanent Contribution to Russia'}

The complexities of AMAR'S effort to equip and open an American hospital in Moscow provide fascinating insights into the workings of individual and organisational relationships on a national and transnational level, where mutual trust and cooperation could quickly turn to suspicion and tension. Trust was paramount if the hospital project was to succeed. In the context of US-Soviet relations after the war, trust was not given or taken lightly. And, we should remember that the climate of mistrust in which these players were operating was not 'created' by international relations or events, but rather, as Haas avers, 'confirmed' by them. ${ }^{18}$ It was, after all, Soviet domestic ideology that informed policy and public opinion in the Soviet Union. The 'capitalist', 'bourgeois' West was the enemy irrespective of whether relations were good or bad. Likewise, Russia stood in ideological opposition to the West. The case of the American hospital project is particularly pertinent because it exposes the inner workings of the way in which individuals and collectives got on with business in the shadow of international politics and power-relations.

American Medical Aid to Russia was formed in late 1921 by a small group of Americans interested in seeking to improve the medical situation in Russia. Based at 103 Park Avenue, New York, AMAR became a serious player on the Russian relief scene. ${ }^{19}$ It was not officially affiliated with other major relief organisations, instead preferring to work through its own special committee of experts, who favoured working in close cooperation with the AFSC. ${ }^{20}$ Although it was affiliated with the Russian government (through the Narkomzdrav [Commissariat of Public Health]), it did not have any association with the Russian Relief Fund or purchase supplies through the Russian Red Cross. Since it succeeded the 'Soviet Russia Medical Relief' Committee (disbanded in the autumn of 1921), it claimed to be the only group exclusively offering medical aid to Russia. ${ }^{21}$ Perhaps this claim afforded AMAR greater propaganda clout amongst American donors, especially those working in medicine.

Along with other organisations such as the Jewish Joint Distribution Committee, AMAR maintained close ties with the AFSC, which was already operating and distributing supplies in Russia. By early 1922, AMAR had found a more definite purpose: to raise funds to open an American hospital in Moscow. The committee had come to this decision based, apparently, on Commissar of Public Health, Nikolai Semashko's advice, and worked closely with Narkomzdrav and its representatives. ${ }^{22}$ Both AMAR Executive Secretary

\footnotetext{
${ }^{18}$ Haas, op. cit. (note 16), 300.

${ }^{19}$ Its Chairman was Mrs Henry Villard and its Treasurer was Arthur S. Leeds. By March 1922 it was claiming in its publicity pamphlet on the American hospital to be distributing medical supplies in conjunction with the AFSC and endorsed by the National Information Bureau.

${ }^{20}$ AFSC, FS, Russia. Letter from Executive Secretary of AMAR to Wilbur Thomas, 29 December 1921. In this letter Witherspoon was seeking official Quaker endorsement.

${ }^{21}$ AFSC, FS, Russia. Letter 9 March 1921 from Executive Secretary to Mr Hall Finch.

${ }^{22}$ AFSC, FS, Russia. Reports, Numbered 1922. Friends of Soviet Russia 1922. Letter 9 February 1922 to
} 
Frances Witherspoon and Semashko hoped that the hospital would eventually become a base for sending medical units to other parts of Russia. ${ }^{23}$ This was an ambitious goal, but with Soviet and American support it seemed feasible. Moreover, AMAR emerged at a time (1921-24) when icy US-Soviet relations were beginning to thaw somewhat.

In order to raise funds for medical assistance, AMAR approached a number of prominent philanthropists, organisations and financiers. As the only group with the exclusive objective of providing medical relief, it sought to direct all other medical funding through its channels. The hospital, Witherspoon informed donors, would be 'a permanent contribution to Russia' and 'help standardise the whole of public health service' there. ${ }^{24}$ Furthermore, she made it known that the 'urge' for the hospital came from the Russian government. With the explicit support of the Russian authorities, AMAR's appeal assumed an air of legitimacy and urgency. Potential donors were to be reassured and encouraged by Russian involvement; if it was a collaborative effort between Russian and American agents, then surely it would have a chance of succeeding. The initiative promised much. Perhaps cooperation through mutual involvement in medical work would lead to some kind of more general US-Soviet rapprochement? In any case, the immediate objective was achieved. AMAR, indeed, managed to bring serious donors on board. The National Committee of Physicians and Surgeons, the National Trade Committee of Manufacturers of Medical Supplies and the American Quakers all contributed through donating drugs and funds for hospital equipment. AMAR would also be sending to Moscow an X-ray machine, surgical department, laboratories, beds and linen. In cash and merchandise they had raised $\$ 55000$, but, in order for the hospital to open in the summer or autumn of 1922 , a further $\$ 10000$ was needed to cover the kitchen, laundry, a disinfectant chamber and ambulances. ${ }^{25}$ If realised, the hospital would be a major boon for the chronically under-supplied Russians, as well as an impressive and symbolic achievement for AMAR.

There were a number of key personalities involved in the AMAR effort. The official head of AMAR was Dr Michael (aka Mikhail) Mikhailovsky, who was the official Russian Commissariat of Health representative in New York. ${ }^{26}$ AMAR's chairperson was Fanny Garrison Villard, while it's Executive Secretary was the writer and pacifist Miss Frances Witherspoon. ${ }^{27}$ It was Witherspoon who oversaw most of the day-to-day running of its affairs and fundraising efforts. ${ }^{28}$ Mikhailovsky, Russian-born but holding US

Mr B. Martin, from Executive Secretary (hereafter: Witherspoon). Originally, the plan had been to conduct emergency aid work in the Volga district, but Semashko intervened and advised that work be done in the city instead. Thus, the hospital project came about. It was then hoped that the hospital would be a base for sending aid to other parts of Russia. The personal involvement of the Commissariat for Public Health representatives in soliciting foreign aid was not unusual and in fact encouraged. See Trott, op. cit. (note 9), 171.

23 AFSC, FS, Russia. Witherspoon wrote in February 1922.

24 AFSC, FS, Russia. Witherspoon to Herbert Fleishacker, president of the Anglo-American Bank in San Francisco, 24 February 1922.

25 AFSC, FS, Russia. Letter 23 June 1922 to Mr Doeller, Cincinnati from Executive Secretary American Aid to Russia. They had spent $\$ 31000$ through the Committee.

${ }^{26}$ The Commissariat of Public Health had representatives abroad in the 1920s, including most notably the very active Mikhailovsky in New York, Goldenberg in Berlin, and Alexandre Roubakine in Paris. There were also representatives in other countries, including the United Kingdom.

27 AFSC, FS, Russia. Fanny Garrison Villard (1845-1928) was wife of Henry Villard and daughter of William Lloyd Garrison. In 1881 the Garrison family inherited both the New York Evening Post and The Nation (her son, Oswald Garrison Villard, became owner and editor of the latter). After the death of Henry Villard in 1900, Mrs Villard remained active in reform and peace movements. She founded the Women's Peace Society and in 1921 she was delegate to the Women's International Conference for Peace and Freedom, held in Vienna.

${ }^{28}$ Frances May Witherspoon (1886-1973) graduated from Bryn Mawr in 1908 and moved to New York 
citizenship, was a major player in the effort to organise the American hospital in Moscow. Both Semashko and Witherspoon trusted him. Correspondence between AMAR and the AFSC suggests that Mikhailovsky was very well-connected in the United States. The AMAR campaign, which he directed, sought to reach every physician in America. ${ }^{29} \mathrm{He}$ corresponded with major philanthropists and America's most eminent physicians. Other important figures included his counterpart in Berlin, Dr Ia. R. Goldenberg, as well as Dr I. Kotzva and head of the Quaker German Mission, Francis Bacon (who was replaced in the summer of 1922 by Gilbert MacMaster). ${ }^{30}$ Francis Bacon was to act as purchasing agent and liaise with Goldenberg and Kotzva. He was important as a go-between and an 'American'; AMAR was an American relief agency and it thus needed to have 'actual' Americans involved. ${ }^{31}$ Consequently, both Mikhailovsky and Wilbur K. Thomas (AFSC Executive Secretary, 1918-29) agreed that an American representative on the ground in Russia was necessary and that it should be Quaker workers who ensured that medical supplies reach the hospital and be used for their intended purpose. ${ }^{32}$ With such open communication and a willingness to cooperate evident on all sides, the omens were good. Still, one of the key questions raised by this new US-Soviet joint venture was whether the alliance would actually work. Could Russians and Americans work together to establish the hospital in Moscow?

\section{Building Trust in Berlin}

Initially, all seemed to go according to plan. Fundraising was undertaken in the US, and most of the equipment was sourced and purchased in Berlin. ${ }^{33}$ Goldenberg, Kotzva, and Bacon were those primarily responsible for overseeing this. The former two answered to the health authorities in Moscow, and Bacon to Quakers in the US. AMAR itself had no foreign-based representative of its own, and was entirely reliant on communication with the AFSC in Philadelphia and Mikhailovsky in New York. It did not have direct contact with Goldenberg, Kotzva or Bacon. More problematic still, Goldenberg and Kotzva were frequently in Moscow and it sometimes proved difficult to get hold of them, a difficulty that directly affected AMAR's ability to act. ${ }^{34}$ Such an arrangement placed serious stress on the relationship between AMAR and Moscow. Therefore good communication and trust would prove pivotal. The Quakers chose Bacon to oversee matters in Berlin and so, at this point, much of AMAR's work had become the responsibility of this organisation,

in 1913. She was co-founder and Executive Secretary of the New York Bureau of Legal Advice. She was involved in movements for women's rights, civil rights and world peace. Her personal collection is held at Swarthmore College. See http://www.swarthmore.edu/library/peace/DG051-099/dg089MygattWitherspoon.htm (accessed 5 August 2013).

${ }^{29}$ See AFSC, FS, Russia. Correspondence in US (D) 22 April 1922 letter to Ms Muriel Draper from Acting Secretary of American Medical Aid to Russia. Committee members included Dr Mayo, Dr Barker (Professor of medicine at Johns Hopkins University), Dr Cushing (Professor of Surgery at Harvard University) and Dr Ireland (Surgeon-General of the US Army). The AMAR campaign was supported by leading medical societies as well as individual physicians and manufacturers, druggists and dealers of medical supplies.

30 AFSC, FS, Russia. Thomas-Witherspoon-McMaster 1922. Letter to Miss Witherspoon from WKT, 1 March 1922. In this letter it was stated that the German person who had worked closely with the Quakers was Dr Ernest Rost who was 'satisfactory, capable, and trustworthy' and could be relied upon to place orders if necessary.

${ }^{31}$ For more on this and Herbert Hoover see 'When Politics and Philanthropy Collide' section below. See also AFSC, FS, Russia. WKT to Witherspoon, 1 March 1922.

32 AFSC, FS, Russia. Letter from AMAR Executive Secretary to WKT, 19 March 1922.

33 The US government trade embargo of July 1920 did not extend to medical supplies.

34 AFSC, FS, Russia. Bacon to Thomas, 15 March 1922. 
which happened to have people on the ground in Germany and Russia. Having someone 'on the ground' was vitally important. It was of even greater importance that this someone was American. ${ }^{35}$

When Bacon met Goldenberg and Kotzva in the Russian Consulate in Berlin, he was impressed by their 'sincerity and zeal'. ${ }^{36}$ Goldenberg, a surgical specialist, was described as a middle-aged man of Russian nationality who spoke German. He had never been to America but was able to read, though not speak, English. Kotzva, also Russian but a naturalised American citizen, was younger - about thirty-five years old - and had spent nine years in the US where he studied at George Washington University. He now seemed to be working as a General Practitioner in surgery. ${ }^{37}$ Mikhailovsky had brought him on board and he was to act as hospital superintendant. Both men welcomed and approved Quaker involvement in the Russian medical effort. AMAR enlisted their help to purchase the X-ray machine, biological laboratory, chemical laboratory, surgical department and drugs. All purchases were to be bought from German firms and paid for through German banks. ${ }^{38}$ This was not unusual and was public knowledge. ${ }^{39}$ The Quakers also purchased medical equipment in Germany during the 1920s because it was considered to be most cost-effective owing to the depreciation of the Mark. Although spending American dollars in Germany could not be considered a politically popular move in the US, it made practical sense at the time. It also showed that, at least in the area of philanthropy, international cooperation could succeed for the sake of expedience.

In spite of continued cooperation, maintaining trust was proving difficult because AMAR did not have complete control over its operations. Accepting that it was difficult for AMAR to have a person on the ground in Moscow, surely it would have made sense to have someone in Berlin to liaise with the Russians and Quakers, but be directly answerable to AMAR? It is helpful to recall the state of international relations at this time, with Russian support for attempted revolution in Germany in 1921 (and again in 1923). The Soviet Union and the West were engaged in trying to preserve a period of detente and peaceful coexistence, but conflicts and heightened tension arising out of Soviet actions punctuated such periods. ${ }^{40}$ Consequently, it should be remembered that healthcare representatives such as, inter alia, Witherspoon, Thomas and Goldenberg were operating in an unstable political environment.

In May 1922 the alliance encountered its first test. There were problems with bank transactions in Berlin; Goldenberg was in Moscow and had not made arrangements regarding medical supplies. Eventually, it transpired that money sent to Berlin by AMAR had not been spent. ${ }^{41}$ AMAR needed to contact Goldenberg to resolve some of these issues. AMAR could not do this directly because it had to go through Bacon to contact Goldenberg. This hindered AMAR's ability to act in a timely manner, with delays leading

35 AFSC, FS, Russia. Letter from AMAR Executive Secretary to WKT, 19 March 1922. Susan Gross Solomon, 'Knowing the "Local": Rockefeller Foundation Officers' Site Visits to Russia in 1920s', Slavic Review, Vol. 62, No. 4, 2003, 710-32 (719).

36 AFSC, FS, Russia. Bacon to Thomas, 15 March 1922.

37 AFSC, FS, Russia. Bacon to Thomas, 15 March 1922. Bacon did not communicate any further information.

${ }^{38}$ Involved here was Dr Hammer, a member of the Advisory Board in America who was overseeing some of the banking transactions. He had recently come from Moscow and was in Berlin. AFSC, FS, Russia. Bacon to Thomas, 15 March 1922.

${ }^{39}$ See AFSC, FS, Russia. Witherspoon to WKT, 28 February 1922.

40 Stephen M. Walt, Revolution and War (Cornell and London: Cornell University Press, 1996), 195.

41 AFSC, FS, Russia. Letter from Bacon to WKT, 1 May 1922; Bacon to Goldenberg, 29 March 1922; AFSC, FS, Russia. Letter from Witherspoon to WKT, 9 May 1922. 
to uncertainty. Goldenberg was rumoured to be about to return to Berlin, but this was not definite, and Witherspoon was anxious to obtain news from him, because it had been assumed that the hospital supplies were 'purchased long ago.' The matter was complicated further by the fact that AMAR was reliant on information from Thomas, but Thomas, in turn, was dependent on his people on the ground in Moscow. The triangulation between the US, Germany and Russia led to confusion, with mixed reports reaching Witherspoon in New York. Again, the absence of an AMAR representative in Berlin and/or Moscow was problematic.

Goldenberg returned to Berlin in May and so Witherspoon could rest easy knowing that he and Bacon were 'harmoniously and satisfactorily' purchasing hospital equipment for the American hospital. ${ }^{42}$ In July, Bacon was due to leave Berlin, with his replacement, Gilbert MacMaster, to continue collaborating with AMAR and Goldenberg. By December 1922 Goldenberg had apparently received all equipment for the hospital from the German firms. ${ }^{43}$ The problems in Berlin, heightened by AMAR's slow reaction and lack of direction, seemed to have been resolved when the purchases were ready for delivery to Moscow. AMAR had placed a great deal of blind trust in its Russian colleagues. Would Witherspoon's faith in Mikhailovsky, Goldenberg and Kotzva prove to have been misguided? The situation that unfolded highlighted some salient points about international partnership during the 1920s. Local level players trusted their 'ideological enemies' (whether by choice or necessity). Removed from the political scene and the international spotlight, it was medical care and pragmatism, not national security and ideology, that was at stake. 'Ideological enemies' became people working together to achieve a common goal.

\section{Providing 'Proper American Control' in Moscow}

Thus far, the AMAR experience suggests that trust and communication were the fundamental ingredients to successful cooperation. But trust was tested again, this time in Moscow. AMAR had no representative of its own there, in spite of Thomas strongly advising Witherspoon to have 'some American doctor' in place to supervise the distribution of medical supplies. ${ }^{44}$ Instead, AMAR requested that Quakers oversee the distribution of supplies. ${ }^{45}$ Witherspoon considered that sending someone to represent AMAR in Moscow was 'foolish', believing it more prudent to save costs and let Quakers oversee all distribution. ${ }^{46}$ This was no small task for the limited AFSC personnel, especially as shipments were sent fortnightly. Without this vital practical support from the AFSC, one wonders how AMAR would have managed. Quaker Caroline Norment, based in Moscow at this time, was dealing with the health authorities there and she seemed none too impressed by AMAR. The additional workload worried Norment, who wanted minimal responsibility for the hospital in Moscow. As far as she was concerned, the AFSC was simply supervising the purchasing of supplies in Germany. ${ }^{47}$ She expected that AMAR, if it was to live up to its promises, would 'send American doctors and nurses

42 AFSC, FS, Russia. Letter dated 2 June 1922 from AMAR to Sybil Moore.

43 AFSC, FS, Russia. Letter dated 16 December 1922, Witherspoon wrote to Thomas.

44 AFSC, FS, Russia Thomas-Witherspoon-McMaster 1922. WKT to Witherspoon, 10 March 1922.

45 Copy of letter to sent by WKT to Mr Carlton H. Palmer, President of E.R. Squibb and Sons Company, New York, 7 April 1922. AFSC, FS, Russia.

46 AFSC, FS, Russia. Witherspoon to WKT, 10 March 1922.

47 AFSC, FS, Russia. Correspondence. Letters from Philadelphia to Russia. Letter from Norment to WKT, 9 June 1922. 
to head up the whole, take some money responsibility, and make a big contribution to Russian science and Russian health.' As it was, she saw serious problems with the entire enterprise.

Norment was one of the few people who had actually seen the Old Catherine hospital (AMAR people had no idea what condition it was in, relying on third party reports). The Old Catherine Hospital was the oldest hospital in Moscow, established under the reign of Catherine II in the later 1771. Of its nineteen buildings, she reckoned that only four or five newer ones - if repaired - could be used. The rest would need to be demolished. ${ }^{48}$ She wanted to know if AMAR realised that they were expected to effectively assume the burden of all costs associated with the hospital, including fittings, staffing and so on. Semashko was too busy to deal with the matter, she claimed, and had placed Kotzva in charge. Norment seemed to trust Kotzva, as he gave the impression of being 'intensely careful about the handling of funds, etc'. Still, Norment expressed concern over the sheer scale and size of work that had to be undertaken in order to make the hospital into a proper, well-run medical institution.

Norment was worried by Kotzva's estimates, which she considered much too low. For example, by his calculations, there would be 600 blankets for 500 beds. Although she reiterated that she thought the project was a good one and that Kotzva was 'thoroughly wrapped up in it', wanting to see it through to 'serve Russia and humanity', she was still seeking more detailed information and reassurances. Norment was furious at an AMAR advertisement in The Nation which claimed that AMAR was distributing through the AFSC. Norment argued that AMAR had 'no right, in the present state of personnel' to do this. Aside from Walter Wildman in the office, Norment was the only Quaker in Moscow at the time and she felt that she had enough to do without taking on the AMAR hospital project. At this point, the interactions between the different personalities came to the fore and the delicate balancing act of managing the hospital project became more difficult to achieve.

Another problem was that of policy. Norment wanted AMAR to carefully consider and discuss its plans for the hospital with Moszdrav (the Moscow health authority) and advised that AMAR get its own medical representative in Moscow. Norment had met with Dr Nahum Kavinocky, a Russian born American physician from Los Angeles who seemed to have become involved in the AMAR project through Mikhailovsky. She claimed that Kavinocky (who had not seen the hospital site) had not really discussed the hospital with the proper authorities. ${ }^{49} \mathrm{He}$ was, at least, informed as to goings on in Berlin, and, she remarked, 'was very much pleased' with how Goldenberg and Bacon had handled the money. ${ }^{50}$ Kavinocky indicated that the AFSC take the 'same sort of Trusteeship' in Moscow, 'acting as joint Controllers of their account in the Moscow Bank, and that all checks be signed jointly by us and the person named as their agent, simply as an assurance of good faith to their public in America' ${ }^{51}$ The AFSC was again being nominated for additional responsibility in the AMAR affair. Perhaps Norment's concern was justified. In any case, her views were bound to shake AMAR.

\footnotetext{
48 AFSC, FS, Russia. Correspondence. Letter from Philadelphia to Russia. Letter dated 6 July 1922 Wilbur Thomas enclosed extracts (extracts dated 9 June 1922) from Norment.

49 AFSC, FS, Russia. Correspondence. Letters from Philadelphia to Russia. Letter from Norment to WKT 3 August 1922 discussing meeting with Kavinocky and Kotzva.

${ }^{50}$ Ibid.

51 AFSC, FS, Russia (Thomas-Witherspoon-McMaster). Letter from Sybil Moore to Louis Miller (AMAR), 9 August 1922.
} 
Indeed, Witherspoon sought clarification on a number of issues touched on by Norment. She was 'troubled' by Norment's reservations about the hospital and especially over relations between the AMAR Committee, the hospital Board of Control and Moszdrav. ${ }^{52}$ Witherspoon was also perturbed by Norment's doubts concerning the amount of money necessary to run the hospital and the 'acceptability' of Kotzva. Thomas tried to put Witherspoon's mind at ease by claiming that Norment was 'always apprehensive about such movements and is quite apt to write very freely about these difficulties in her own mind'. ${ }^{53}$ In a diplomatic move, Thomas noted that everything was going well and that AMAR could always call on the Quakers. This seemed to reassure Witherspoon. ${ }^{54}$ Whether or not Thomas actually believed this, he was no doubt managing the situation.

A second letter from Norment portrayed a particularly gloomy picture of developments in Moscow. Norment had met with Mikhailovky and Kavinocky and accompanied them to a meeting with a Moszdrav representative to discuss plans for the hospital. No agreement with the government had been signed and, consequently, little progress, in her view, was being made. Since the meeting, Mikhailovsky had returned to the US and Norment had met with Kavinocky just once, at her request. She enclosed a copy of the proposed agreement for the hospital which, she claimed, made no provision for 'actual direction for the work to be done by an actual representative of the American Medical Aid'. Norment and Wildman, as well as Alan Wardwell and Allan Burns from the National Information Bureau ${ }^{55}$ considered the agreement to be an 'unsound' basis. Norment (and the Quakers) wanted an American in control to direct policy given that American funding was being used and that the organisation bore 'America' in its title. With strong anti-western rhetoric in Russia, Narkomzdrav would have serious trouble publicly acknowledging US support. The whole matter, according to Norment, was 'full of pitfalls and dangers'. As things currently stood, Norment wrote, the hospital would not open for several months. No supplies had been distributed (these were slow coming from Berlin and delayed in Petrograd) and no administrative responsibility had been taken. Ultimately, as Norment told Kavinocky, the Quakers were content to act as guarantors, but responsibility was AMAR's.

Should Witherspoon have trusted American rather than Russian reports? Were the Russians concealing the lack of progress with the hospital, or were they genuinely in the dark? In December 1922 developments in the US triggered AMAR to rethink its plans for the hospital. As Norment had indicated, Alan Wardwell, head of the Russian Commission of the National Information Bureau, did not like the agreement with Moszdrav because it did not 'provide for proper American control', understood by Witherspoon to mean a committee in America with a primarily American Board of Directors in Moscow. ${ }^{56} \mathrm{He}$ also wanted an experienced American superintendent to be in charge of the hospital. The latter point was, for Witherspoon and AMAR, 'out of the question' because the whole point was to 'help the Russians help themselves' and they should select a Russian to head

\footnotetext{
52 AFSC, FS, Russia. Letters Russia-England. Witherspoon to Sybil Jane Moore, AFSC Assistant Secretary, 7 October 1922.

53 AFSC, FS, Russia (Thomas-Witherspoon-McMaster). Letter from WKT to Witherspoon, 11 October 1922.

${ }^{54}$ AFSC. Letter to WKT from Witherspoon, 16 October 1922.

55 AFSC. The NIB was established in 1918 and functioned as a clearinghouse for American philanthropies. AMAR received endorsement on 16 May 1922, but this would be discussed again later that year after Wardwell (Chairman of the Committee on Russian Relief), Burns (Director), and Eversole completed an NIB survey mission in Russia.

56 AFSC, FS, Russia (Thomas-Witherspoon-McMaster). Letter from Witherspoon to Thomas, 16 December 1922. For more on this see the 'When Politics and Philanthropy Collide' section below.
} 
up the hospital. The meeting had apparently been 'friendly and helpful', but Witherspoon still seemed despondent and was at a loss as to what to do. She considered it might now be best to share responsibility with other organisations (by February-March 1923 this became a reality as AMAR became the Medical Division of the AFSC, but the AMAR Committee was left intact to oversee matters). ${ }^{57}$ The hospital project, initially undertaken with such goodwill, was now becoming the bone of serious contention between not only Americans and Russians, but, even more so, between American organisations themselves. In some respects, the real issue was not one of cooperation between 'ideological enemies', but of cooperation among Americans.

\section{Chinese Whispers and Chilly Winds}

Caroline Norment was not the only Quaker representative in Moscow troubled by how matters were progressing and by AMAR's inaction. Several months after Norment expressed her doubts about the AMAR hospital project, Quaker Julia Branson echoed her concerns. ${ }^{58}$ Branson found that Kotzva, despite being hard at work, was hopelessly overwhelmed. AMAR had left him to take care of everything with the result that he had to personally supervise the opening of all shipments. If these were held up in Petrograd (which was frequently the case), he had to go there himself to investigate instead of organising the hospital in Moscow. ${ }^{59}$ AMAR had not made any provisions for practical support, assuming that the Russians and AFSC had the matter in hand. Sharing Norment's doubts, Branson wanted to know AMAR's position and whether it could be trusted to complete the hospital project. She felt that the physicians working in the hospital seemed very good and deserved to know whether AMAR would deliver, as they were 'getting anxious to see some tangible evidence of the promises made' ${ }^{60}$ Trust could only go so far. Without practical results it was becoming more difficult to sustain one's faith. Given the extremely trying economic circumstances in Russia at this time, the passage of several months without the arrival of supplies diminished any hopes of seeing the hospital open in the near future.

Witherspoon placed a great deal of responsibility on interlocutors, and therefore greater direction and more authoritative communication might have helped AMAR. Or, as Thomas and Norment had suggested, a person in Moscow, even a doctor or nurse in the hospital, who was directly answerable to AMAR might have cleared some of the communication lines, making AMAR more self-reliant. The history of Quaker efforts in Russia shows a finely-tuned sense of knowing the balance between give and take. ${ }^{61}$ The Committee in Philadelphia and workers on the ground were keenly aware of financial limitations and found ways to adapt to and work around these while still getting results. AMAR desperately wanted to open the hospital and satisfy all those involved, but by diluting its authority through third parties, it inadvertently lost control. Even though it could only feasibly operate through the distribution channels of the AFSC or the ARA, this did not mean that its hands were completely tied. Instead, it failed to provide additional assistance

\footnotetext{
57 See AFSC, FS, Russia. Witherspoon to Kavinocky, 3 May 1923.

${ }^{58}$ For more on the internal divisions among the Quakers concerning Thomas and Hoover, especially developments in the mid-late 1920s, see McFadden, op. cit. (note 7), 75-8.

59 AFSC, General Files-FS Russia (Medical Aid to Russia). Letter from Julia Branson to WKT, 3 January 1923.

${ }^{60}$ AFSC, FS, Russia. Branson to WKT, 3 January 1923.

${ }^{61}$ For more on 'giving and taking', see Susan Gross Solomon and Nikolai Krementsov, 'Giving and Taking Across Borders: The Rockefeller Foundation and Russia 1919-28', Minerva 39 (2001), 265-98.
} 
on the ground by deciding to cut costs. Problems in Moscow provided further evidence that AMAR was no longer able to run affairs without the official support of the AFSC. With their solid track record and good relations with Russia, AMAR could not have wished for a better partner than the Quakers. Still, Norment and Branson's fears planted seeds of doubt as to whether the AFSC had enough resources to meet AMAR's needs as well as exert sufficient influence over AMAR's actions. AMAR, after all, was still directing affairs.

Once the hospital was equipped, Mikhailovsky and Kavinocky were to go to Moscow to organise its administration (under the proviso that the Governing Board would consist of Americans with a Quaker representative in Moscow to sit on the Board). ${ }^{62}$ The food supply for the 150 patients, together with 60 physicians, nurses and employees, had, according to Witherspoon, been 'practically promised us by the Quakers, who will appropriate a three month's food supply from the food stores they have already on hand in Moscow. ${ }^{93}$ Witherspoon planned that, in the autumn, they would have a concerted appeal for funds that would take care of hospital provisions, salaries and so on. However, money for the kitchen, laundry, disinfectant chamber and ambulances had yet to arrive. Witherspoon was enthusiastic about the latest reports from Moscow and wrote to Alice Davis that 'we believe we shall open the finest institution in Russia, and one that will even compare favourably with other European hospitals'. ${ }^{64}$ Witherspoon's optimism was somewhat misplaced and soon affairs in Berlin became considerably murky. Debts had mounted. Goldenberg had apparently 'far exceeded his instructions ... in the matter of purchasing hospital equipment' leaving in his wake debts (some \$10 000-\$12 000) that could not be met. ${ }^{65}$ Later, Mikhailovsky and Kavinocky were held responsible as they had put in additional orders, which they expected AMAR to cover. ${ }^{66}$

Relations between the Americans and Russians involved in the hospital project threatened to go from bad to worse after a bizarre and unfortunate series of communications. This time, there was trouble close to the top. In early 1923 an evidently annoyed Semashko wrote to Mikhailovsky inquiring about the lack of information from the AFSC and whether this indicated that their activities were at an end. If this was the case, he noted, the existence of the American hospital in Moscow would be in serious peril. ${ }^{67}$ Mikhailovsky's telegrams had 'caused confusion in Moscow', and Quakers there seemed unable to explain them. ${ }^{68}$ Semashko did not want the issue of Quaker involvement in the hospital discussed by telegraph and requested that, given the difficult situation, Kotzva - as a representative of the American Committee in Russia - should go immediately to Mikhailovsky and resolve the matter. Semashko wanted Mikhailovsky to 'quickly and correctly' deal with the 'crisis' and hoped that he would succeed in expanding ('shiroko razvernut') the

62 AFSC, FS Russia. Letter from Executive Secretary of AMAR to Dr Klemptner, Seattle, dated 20 June 1922.

63 Ibid.

64 AFSC, FS, Russia. Correspondence in US (D), Executive Secretary Anna Davis 29 September 1922.

${ }^{65}$ According to MacMaster, Goldenberg had been a 'careful and intelligent' buyer who had drawn up contracts with large, reputable firms. Letter written by MacMaster to W.K. Thomas, 5 December 1922. MacMaster and Goldenberg felt that these 'represented one of the finest gifts which the city of Moscow probably would ever receive'. Although the installation costs in Moscow would be high, they would be 'worth infinitely more to the sick of Moscow'. In 2015, the sum of $\$ 12000$ is approximately the equivalent to $\$ 162875$ - a considerable debt. 66 AFSC, FS, Russia. Kavinocky, Dr Nahum 1923. Letter to Kavinocky, 5 January 1923.

${ }^{67}$ Gosudarstvennyi Arkhiv Rossisskoi Federatsii (hereafter GARF), f.482, op.35, d.55. Semashko to Mikhailovsky, 3 February 1923.

${ }^{68}$ Ibid. 
work of the AFSC. ${ }^{69}$ Quakers, in the meantime, learned that Semashko had received a telegram from AMAR implying that there has been some misunderstanding or lack of cooperation between Dr Catzva [sic] and our office here, and requesting that they do cooperate with us'. ${ }^{70}$ This seemed ominous and odd, as Julia Branson claimed that she had in fact held many discussions with Kotzva during which they had been in 'thorough agreement' ${ }^{71}$

The division of responsibilities had created confusion and literally caused wires to cross. Branson felt that her "wire stating that it would be impossible to take charge of supplies implied that the Narkomzdrav would not allow us the desired freedom regarding the supplies'. On the contrary, she had been 'perfectly unwilling to even discuss the matter with the Narkomsdrav [sic]' because she felt 'that under the contract of the American Medical Aid with the Moscow Health Department, we had no possible right to touch the supplies. Dr Catzva [sic] also feels that we cannot possibly divert them from the socalled American hospital'. She hoped that Thomas would 'correct the impression with the AMAR that there has been any lack of cooperation' as she and Kotzva had 'seen nearly eye to eye on the matter' ${ }^{72}$ In this case, Kotzva seemed stuck in the middle, dealing with the Russian health authorities on the one hand and AMAR's Mikhailovsky on the other. A sort of Chinese whisper had occurred, as Branson's opinions filtered through Kotzva to Mikhailovsky and on to Semashko, with a different meaning coming out at the other end. The delays in correspondence, ranging from letters to cables to wires and radiograms probably did not help the situation. ${ }^{73}$ Kotzva had simply found himself in an unfortunate position as intermediary. If word had not got back to Branson, who clarified the matter, this 'misunderstanding' could very well have had serious repercussions. AMAR might have damaged the excellent relations that had been cultivated between Quakers and Russia. Or, it might have been the end of the hospital project and precious medical supplies. Juggling international communication, financial transactions and inter-organisational cooperation, as well as staying on top of transit and shipping orders was a tall order for a small committee such as AMAR, which was evidently in over its head.

In his argument about the balance of power after the Bolshevik revolution, Stephen Walt maintains that, while the 'Soviets and the onlookers had legitimate grounds for suspicion, each side interpreted the others' actions in ways that reinforced its initial suspicions and inflated the perceived level of threat even more' ${ }^{74}$ The upshot of this, he argues, was that the Soviet 'paranoid view of world politics' meant that tensions and conflict would remain indefinitely. While such 'paranoid' views were not uniquely Soviet, Walt's argument underscores the importance of trust and suspicion in international relations. The role of trust comes to the fore in the story of the American hospital in Moscow. Efforts to push through philanthropic and medical projects were always subject to the changeable winds of national politics and international diplomacy. Irrespective of how much individuals

\footnotetext{
69 Ibid.

${ }^{70}$ AFSC, FS, Russia. Letter from Branson to WKT. Branson had been told this by Kotzva, 6 March 1923.

71 Ibid.

72 AFSC. General Files 1923 FS, Poland to Russia. Letter from Julia Branson to WKT, 6 March 1923.

73 The importance of communication and information is critical here. The problems experienced by those working at this level of the state apparatus were a reflection of those at the very top. See for example Walt's discussion about 'uncertainty and misinformation' in relations between Russia and the West after the revolution. Walt, op. cit. (note 40), 207. Walt argues that a lack of communication, especially direct communication, escalated tensions and undermined attempts at cooperation.

74 Walt, op. cit. (note 40), 203 (Ithaca and London: Cornell University Press, 1996).
} 
trusted one another (or wanted to), if the international current was against them, it was very difficult for them to move forward. The key players functioned in a pressurised domestic environment that directly influenced international relations. It was not easy for individuals and collectives to operate when an atmosphere of suspicion prevailed between and within states. The sphere of healthcare allowed for possible cooperation, but - as the history of AMAR shows - it was nonetheless fraught with difficulties.

\section{When Politics and Philanthropy Collide}

AMAR, by now insolvent, appeared deeply embroiled in what could only be described as a financial disaster. By the end of February 1923 the AFSC, which had taken over AMAR, was paying off AMAR debts, but supplies were still slow to arrive. ${ }^{75}$ The purchasing of supplies in Berlin threatened to become quite a scandal. Debts stood at some $\$ 10090$ in March 1923, although MacMaster warned that there might be more. ${ }^{76}$ Quakers in Philadelphia reacted with great surprise upon learning of "this large sum which was owing in Berlin'. ${ }^{77}$ The AFSC - always on top of its own financial affairs - was utterly taken aback by news of AMAR debts. Quaker Alice Davis, for example, was surprised by 'how deeply involved the situation in Berlin had become, and into what desperate straights [sic] Goldenberg had manouevered himself'. As Davis (who had worked in Samara and dealt with Russian health authorities) understood it, Goldenberg, and not AMAR, was to blame. In a sorry twist of fate, MacMaster reasoned that the only way to avert disaster was to sell the ambulance and some of the hospital equipment. This plan was unlikely to pass muster with the Russians, who, according to Julia Branson, had 'no intention of giving up any of the supplies'. It was hoped that once Thomas and Kotzva met in Berlin, matters would become clear. ${ }^{78}$ The relationship between AMAR, Quakers and the Russians was still under serious pressure.

The AFSC, with vast experience in fundraising and international cooperation, was in an ideal position to help AMAR. Moreover, it had a pristine and hard-earned reputation to protect; once it took over AMAR's affairs in 1923, the AFSC insisted that there be transparency. ${ }^{79}$ Goldenberg, unsure of how to act at this point, wrote to Semashko for instruction. Thomas believed that Quakers had 'dealt with him [Goldenberg] as nicely as possible' and had not offended him, but made it 'plain that there would be no more money given to pay debts, and therefore no more opportunity of getting medical aid through this group unless we could work harmoniously together'. Apparently neither Kotzva nor Goldenberg seemed to understand that AMAR no longer existed and that the AFSC was now in full control. But again, Thomas understood the importance of cooperation.

\footnotetext{
75 AFSC, General Files FS, Russia (Medical Aid to Russia 1923). 3 January 1923, To WKT from Julia Branson and Witherspoon to Haven Emerson. It was noted here that the Russians would take over the hospital 1 January 1924. Letter from Haven Emerson, 28 October 1922 (to Emerson from WKT 24 February 1923), AFSC, FS, Russia. Emerson, Dr Haven.

76 AFSC, FS, Russia. Letter from J. Augustus Codwallader to Witherspoon, 28 March 1923. When Thomas left for Europe he asked that Codwallader write to Witherspoon regarding AMAR's outstanding bills and obligations to the German firm Foerderung. There were other expenses amounting to $\$ 2500$ for a boiler and motors for the hospital. MacMaster had neither known about nor approved these.

77 AFSC, FS, Russia. Letter from Codwallader to Witherspoon, 28 March 1923.

78 Ibid., 1923.

79 AFSC, FS, Russia. Letter from WKT to Witherspoon, 9 April. Thomas had held a short meeting with Goldenberg in Berlin.
} 
Thomas informed Witherspoon that no progress was being made in settling accounts and Goldenberg was 'not very responsive'. ${ }^{80}$ Worse still, the Russians favoured resurrecting AMAR. Thomas was on the ground in Berlin, trying to resolve the AMAR debt problem while dealing with ill-informed and/or recalcitrant Russians, before continuing on to Russia. Not one to mince words, Thomas wrote to Witherspoon that she 'did not really convince them [the Russians in Berlin] that the American Medical Aid to Russia had really gone out of existence'. ${ }^{81}$ Witherspoon had confused matters more by placing an AMAR advertisement in The Survey, leaving MacMaster uncertain of the exact position of the AFSC. Consequently, when updating Goldenberg, he was not as clear as he could have been in conveying that AMAR no longer existed. More or less paralysed in Berlin, Thomas postponed acting further until he met with Semashko. With Thomas in charge, chances of resolving the situation seemed good. Crucially, the AFSC had experience in dealing with medical work in Russia and had established effective channels of communication with their Russian contacts. Thomas was firm but diplomatic, aware of how politics functioned at micro and macro level. The 'tragedy of Soviet diplomacy', Walt claims, was that 'Bolshevik ideology predisposed them to assume the worst about their adversaries' ${ }^{82}$ The history of the American hospital casts the US-Soviet relationship in a different light. Semashko and Narkomzdrav trusted Wilbur Thomas and Quakers. The hospital project shows that trust and cooperation could trump ideology.

Establishing trust in wider circles was always challenging, and cooperation was never achieved easily. This was not only the case between Russians and Americans. Herbert Hoover had emphasised that Americans should have control over the financial administration of all funding agencies. AMAR left much of this responsibility to Russians in Berlin and so did not meet Hoover's approval. ${ }^{83}$ However, the AMAR mess was not necessarily a vindication of Hoover's policy, for the roots of the mismanagement of AMAR lay with Witherspoon in the US. Cooperation between American agencies was just as important as cooperation with Russia. The series of unfortunate events was arguably a consequence of decisions made, not in Berlin or Moscow, but in America. In any case, the Soviet government was, understandably, never amenable to total American financial control. There simply had to be compromise and cooperation. AMAR's legitimacy, Witherspoon noted, came from its association with Mikhailovsky as Narkomzdrav representative working under the orders of Semashko. ${ }^{84}$ Witherspoon could not understand why Hoover should have misgivings about AMAR.

The doubts of highly placed Americans involved in philanthropy plagued AMAR throughout its brief existence. As noted earlier, Alan Wardwell was critical of AMAR's arrangement with the Russian health authorities. ${ }^{85}$ This was even in spite of the fact that he was completely oblivious, as Witherspoon remarked, 'to how really bad our financial situation is'. Wardwell was against the running of the Old Catherine hospital as an American institution and wanted AMAR to support and encourage Russians to run it as a Russian institution, but with AMAR maintaining financial control. If this was not possible,

${ }^{80}$ AFSC, FS, Russia. Letter from WKT to Witherspoon, 3 May 1923. Thomas had hoped that once Mikhailovsky explained the situation, Goldenberg and the Russians would understand. This proved to be true. It was in the end a letter from Mikhailovsky that convinced Semashko's assistant (Katalina) that AMAR had gone out of existence.

81 AFSC, FS, Russia. Letter from WKT to Witherspoon, 3 May 1923.

82 Walt, op. cit. (note 40), 204-5.

83 AFSC, FS, Russia. Letter from Witherspoon to Haven Emerson, 24 February 1923.

84 AFSC, FS, Russia. Executive Secretary to Mrs Olga Klemptner, 24 February 1922.

85 AFSC, FS, Russia. Witherspoon to Kavinocky, 20 December 1922. 
he advised assisting Moscow hospitals more generally through providing equipment and medical relief. Witherspoon and the committee did 'not care at all for this proposal', but acknowledged that it was unable to support the hospital. ${ }^{86}$ Witherspoon, evidently, relented as the American Hospital was to cease being called such (no doubt a popular decision in Moscow too). Any AMAR appeals were to refer only to the Old Catherine Hospital owing to the severe criticism AMAR received for trying to establish an American hospital in Russia, which raised the thorny matter of 'efficiency, business methods, and standards' ${ }^{87}$ Instead, efforts were to focus on simply helping Russians repair and put the Old Catherine hospital back into use, as opposed to running an 'American hospital' per se.

Distanced from the problems in Berlin and practical issues in Moscow, AMAR and the AFSC continued to press hard by raising financial support at home. On Thomas's suggestion, Witherspoon held an interview with Dr Esther Lovejoy of the American Women's Hospitals (hereafter AWH), which wanted a presence in Russia (though Lovejoy expressed doubts over the scale of the hospital project). ${ }^{88}$ Mikhailovsky and Witherspoon were 'very pleased' with how the meeting proceeded. The plan was for the American Women's Hospitals to take over the Maternity Ward and install an American head doctor and head nurse, with all other personnel being Russian. ${ }^{89}$ The 'difficulties' would lie in ensuring that the Russians fulfilled their end of the bargain by providing maintenance and repairs. Witherspoon was certain the AWH could be persuaded to come on board. Given that she actually knew nothing about the state of affairs in Moscow, Witherspoon realised it was necessary to find out what condition the maternity ward was in before committing the AWH to the project. She suggested that they 'put pressure' on Russian friends to do what needed to be done.

It was not long before news of AMAR's financial problems reached American shores and threatened to halt the charity and goodwill of American physicians who contributed to AMAR. Troubled by what he had heard, one physician was disappointed and angry when he learned that AMAR had been 'mismanaged', that not enough funds had been obtained and whatever had been was 'used for foolish purposes'. ${ }^{90}$ The physician also heard that Russia was exporting grain to Germany while Americans were 'feeding the starving Russian children'. If he was to be so generous again, he would need more information before acting. ${ }^{91}$ Public opinion in the US was particularly unfavourable to Russia at this time, with Hoover criticising the Soviet leadership as 'insincere and dishonest' after learning that it was exporting grain. ${ }^{92}$ American physicians who had contributed money were wary, with some hesitant to become involved again until Russia did 'some internal housecleaning' before receiving any more aid. ${ }^{93}$ AMAR's hospital project seemed to be

${ }^{86}$ Ibid.

87 AFSC, FS, Russia. Letter to Kavinocky, 5 January 1923.

88 AFSC, FS, Russia. Letter dated 16 December 1922, Witherspoon wrote to Thomas. The meeting was a luncheon hosted by Lillian Wald. In attendance were three members of the executive board of the American Women's Hospitals (Dr Lovejoy, Dr Gertrude Walker and Dr Wallin), Wilbur Thomas and Dr Haven Emerson (of the National Physicians Committee).

89 AFSC, FS, Russia. Correspondence in US (Dr Kavinocky). Letter to Kavinocky, 9 January 1923.

${ }^{90}$ AFSC, FS, Russia Emerson, Dr Haven. Letter from Walter B. Cannon to Emerson, 14 March 1923. Cannon had heard this from a Miss Bond of the NIB investigating team in Russia.

91 AFSC, FS, Russia. Cannon to Emerson, 14 March 1923. This information had come to him by way of Miss Bond who had been a member of an investigating commission in Russia. In spite of the famine in Russia, the Soviet government exported grain while accepting food and medical relief from the US and Britain.

92 As a response, Hoover wanted to call a halt to all exports to Russia but subsequently eased this stance.

93 AFSC, FS, Russia. Letter from Howard A. Kelly, Baltimore, to H. Emerson, 9 June 1923. 
further poisoning US public attitudes to Soviet Russia, rather than developing a more cooperative relationship.

Head of the National Physicians Committee, Haven Emerson, addressed the concerns of angry US physicians. However, he did not do much to appease the situation by jumping on the 'anti-Soviet' bandwagon and apportioning blame to Moscow. He wrote that in several meetings with the National Information Bureau's Allan Burns, Alan Wardwell and Henry Eversole it became clear that agreements between the AMAR representative in Moscow (presumably Norment or Branson) and Moszdrav had 'proved inadequate' to protect their interests and that medical supplies were still 'crated and unused'. Moreover, the AMAR representative (presumably Kotzva), was described as an 'ineffective and forceless physician' ${ }^{94}$ Trying to salvage the situation, Emerson pointed out that no money had been wasted and the main problem was that they received poor advice and were 'tempted into getting what is really too elaborate permanent equipment for hospitals still lacking the most immediate emergency drugs and surgical tools'. But all was not lost. The AFSC, Emerson noted, had taken over AMAR and would use all supplies to the greatest effect. The Quakers and the AWH, it was implied, would do a much better job than AMAR. His portrayal of Russian involvement was decidedly negative.

Unsurprisingly, the Russian reaction to these latest developments in the US was not good. Mikhailovsky was of course in a prime position to follow developments from his New York base. He wrote to Goldenberg acknowledging his great work but explaining that the Russian campaign had to change. ${ }^{95}$ The return of Allen Burns, Alan Wardwell and others from Russia to the US, and their negative public statements about the visit, had led Mikhailovsky to reconsider the entire Russian approach to medical support. Mikhailovsky informed Goldenberg that the National Information Bureau representatives claimed that the Old Catherine hospital was unsuitable ('nekuda ne goditsya'), that the Moscow health authorities had made no repairs to it and that all the equipment for the kitchen and laundry had not been used. In order to avoid a public scandal and save the Russian aid effort, Mikhailovsky had decided to throw his lot in with the Quakers and undertake a more general campaign for medical aid. ${ }^{96} \mathrm{He}$ wrote to Goldenberg stating that AMAR was now the Medical Division of the AFSC, having autonomy but being financially dependent on the Quakers. ${ }^{97}$ Funding for medical literature would come from the Rockefeller Foundation, but would be a separate venture. Mikhailovky advised Goldenberg to think matters over seriously before replying with detailed information about 'Russia's present needs'. ${ }^{98}$ In conclusion, Mikhailovsky wrote that he wanted Goldenberg to offer 'friendly assistance' to Quakers in Berlin, that Thomas - an 'honest and genuine well-wisher for Russia' - was travelling to Russia, and that Quakers were planning to work in Russia for the next ten to fifteen years. Once the ARA withdrew, he added, everything would be 'in the hands of the Quakers'. As the Quakers were considered more politically neutral than the ARA, this move was favoured by Moscow, especially when relations remained tense between the US and Russia. Mikhailovsky, and ipso facto Russia, was only prepared to trust and cooperate with Quakers.

\footnotetext{
94 AFSC, FS, Russia. Letter from Emerson to Canon, Boston, 15 March 1923.

95 GARF, f.A-482, op.35, d.57, 1.216. From Mikhailovsky to Goldenberg, 18 March 1923 (New York).

96 Ibid., 1.216.

97 Ibid., 1.217 .

98 Ibid.
} 


\section{A Lesson Learned}

When Wilbur Thomas arrived in Moscow to finally settle AMAR affairs, he found Semashko to be 'very keen' and 'most willing to meet us in every way'. ${ }^{99}$ Thomas offered Moscow the carrot of free rein over how supplies were to be used in the hospital. The stick, however, was that the AFSC could provide no financial contributions towards installing any of the larger machinery. This included the ice-machine, laundry, and kitchen (still in Germany or in warehouses). ${ }^{100}$ Overall, it was going to cost the AFSC some $\$ 7000$ to ship the supplies. As Thomas told Witherspoon, Semashko 'had been placed in a very embarrassing situation'. Yet, it seemed that AMAR was in the more embarrassing situation. The Russians in Berlin had erred by bungling the ordering of supplies and equipment, but AMAR and Witherspoon had raised the hopes and expectations of the Russians. AMAR, by creating a sense of uncertainty, did not cover itself in glory. This point was not missed by Thomas, who reprimanded Witherspoon: 'Because of the promises made, and your contract, they had counted on having about $\$ 250000$ a year to run that hospital. The city of Moscow did not appropriate money for the maintenance of this hospital, and they have been running very short of supplies since January 1'. The financial mismanagement and inept handling of affairs by Moscow, but more particularly by AMAR, had marred the whole enterprise. Witherspoon's good intentions and promises to Moscow had led to great plans that now seemed unrealisable. Ultimately, Thomas, despite the AFSC assuming all debts, let Moscow have practically all the supplies and equipment so that they could enjoy 'the privilege of distributing them to other hospitals'. ${ }^{101}$ This was not the grand plan initially envisaged, but it did satisfy Semashko's objective of having a well-equipped hospital in Moscow.

For months AMAR had been struggling to run affairs and in early summer 1923 it admitted that plans for the hospital had fallen apart, with agreements broken on both their and the Russian side. The amount of money that needed to be raised was simply too great, so it handed over all equipment to the Russian health authorities. ${ }^{102}$ AMAR had now divested itself of any responsibility regarding the hospital project; as far as it was concerned there was 'no American hospital in Moscow'. In a letter to Kavinocky, who seemed to have returned from Russia with enthusiasm but then had distanced himself from AMAR, Witherspoon acknowledged that there had been 'misunderstandings' in Berlin and that their affairs were 'in very bad shape'. ${ }^{103}$ Even with AMAR officially off the scene and the Old Catherine hospital under the direction of the AFSC and AWH (until January 1924, when Narkomzdrav would assume control), the repercussions of its actions were still reverberating in Berlin. In November 1923, AMAR's books were audited. ${ }^{104}$ The audit presented serious problems and it was feared that invoices might 'not prove very much if there are political reasons for the audit'. The supplies, it transpired, had all been bought

\footnotetext{
99 AFSC, FS, Russia. WKT to Witherspoon, 3 May 1923.

100 AFSC, FS, Russia. WKT to Witherspoon, 3 May 1923. The AFSC had warehouses in Russia and Germany.

101 AFSC, FS, Russia. WKT to Witherspoon, 3 May 1923. They did request a statement as to where all of the equipment was placed.

102 AFSC, FS, Russia. Correspondence in US (H). Letter from Witherspoon to Hubbard, 1 May 1923. Hubbard was a nurse who had hoped to work in the hospital in Moscow. Writing to a Mr Franklyn Hubbard of General Delivery, Winnipeg, Manitoba.

103 AFSC, FS, Russia Kavinocky 1923. Letter to Kavinocky, 13 May 1923. It was understood that Thomas and Dr Goldenberg had settled affairs. Dr Kotzva, of Narkomzdrav and who had been in the US for about a month, was to ensure on his return to Russia that all the supplies would be transferred to the Quakers.

104 AFSC, FS, Russia. Berlin to. Letter from MacMaster to WKT, 28 December 1923.
} 
in Goldenberg's name in order to save money. For this reason, there were no links to an American account. ${ }^{105}$ However, there was no further discussion of the audit, suggesting that the matter was resolved - a further crisis had been averted.

Although Witherspoon and AMAR seemed to have extracted themselves from a tricky and potentially politically disastrous situation by joining forces with the AFSC and AWH, the troubling experience must surely have left negative impressions on those who had been involved in the hospital campaign. Quaker Alice Davis, for one, was nervous and worried that Goldenberg's 'wreckless manner' of buying might end up causing 'another scandal like the Old Catherine hospital'. ${ }^{106}$ The AMAR hospital affair had tarnished the image of those involved, whether in the eyes of American physicians, the AFSC or in Moscow. As Davis indicated, the AFSC would have to pull together and work hard to keep their work 'honest'. No doubt, it was keen to distance itself from AMAR. However, the AFSC came out of the scandal with its reputation intact and according to Allan Burns it was 'a perfectly solid and reliable organisation now' ${ }^{107}$ In her final report to Thomas, Julia Branson detailed her visit to the hospital with Kalina, head of the Moscow Health Department. Although all the supplies were in Moscow, only the general equipment, operating room equipment and the X-ray apparatus were in the hospital. ${ }^{108}$ Russians were appreciative. Kalina informed Branson that he would soon send Mikhailovsky a final report 'with an open letter of thanks to the American givers'. ${ }^{109}$ Thanks to Quaker assistance, the AMAR story had a happy ending. Relations between the US and Russian agents were certainly tested during the affair, but no lasting damage was done. The intervention of the AFSC rescued the entire project and showed that medical work, when undertaken by experienced and skilled interlocutors, could prove successful and beneficial.

\section{Conclusion}

The story of AMAR involvement in Russia sheds light on a number of fascinating processes and interactions in the 1920s. Accounts of the work of relief agencies during this time have shown how important these interactions were in the work that was undertaken, and also how national policy and international relations impacted on their operations. However, there has not been the kind of detailed, micro-based study of communication, as examined here. The three-way correspondence between the US, Russia and Germany testifies to the scale of the project undertaken and the immense difficulties involved in managing logistics and communication. Most of all, it points to the importance of trust and experience. Without these, international cooperation founders. In the early 1920 s it seemed as though fundraising was almost de rigueur for high society, a gesture of goodwill from wealthy philanthropists to famine stricken Russia. The political climate was of course a key issue, and by early 1923 it was becoming harder to raise money for 'red' Russia. The short and rather fraught existence of AMAR exemplifies the immense goodwill of American physicians, nurses and other medical workers to really help Russians access better medical care. This encapsulated all that was good about fundraising and philanthropy. It was the way AMAR went about this, however, that revealed the problematic nature of fundraising.

\footnotetext{
105 Ibid.

106 AFSC, FS, Russia (Medical aid to Russia 1923), Alice O. Davis to WKT, 15 August 1923.

107 AFSC, FS, Russia (Medical aid to Russia 1923), Alice O. Davis to WKT, 15 August 1923.

108 AFSC, FS, Russia. Correspondence. Letters to Philadelphia from Russia. Letter from J. Branson to WKT, 21 January 1924.

${ }^{109}$ AFSC, FS, Russia. Correspondence. Letters to Philadelphia from Russia. Branson to WKT, 21 January 1924.
} 
By placing so much trust and responsibility in the hands of those whom it knew very little about, AMAR more or less surrendered its right of control. Its Executive Secretary, Frances Witherspoon, seemed to willingly abdicate responsibility to the AFSC and Russians in the US, Moscow and Berlin without ever really directing matters. The financial catastrophe in Berlin, though somewhat harshly blamed on the Russians, was just as much the fault of AMAR and its inert leadership.

International philanthropy was inextricably bound up in politics and international relations. AMAR, although aware of this, seemed content to pay minimal heed, instead favouring an idealistic and somewhat naive approach to rendering aid to Russia. Had it not been for the Quakers and the experienced counsel of Wilbur Thomas, AMAR could well have found itself in deeper trouble than it did. Witherspoon, Mikhailovsky, Goldenberg and Thomas all shared the same objective of wanting to help Russia, but the tangled web of communication and often poor decision-making of the AMAR Committee complicated an already complex process. This paper has highlighted the problems arising from a joint American and Russian endeavour to establish an American hospital in Moscow, but also points to the problems of intra-American cooperation. Above all, it shows that, during a time of difficult international relations between the US and Bolshevik Russia, American and Russian agents and organisations were willing and able to work together. By working together they ensured that the Old Catherine hospital in Moscow opened and that ordinary Russians could receive much-needed medical services. The X-ray unit and other supplies eventually arrived in Moscow and indeed the Old Catherine hospital did become one of the finest medical institutions in Russia. Even though it was not the 'American' hospital, Russians involved appreciated the American contribution, and ordinary Soviet citizens (though probably not aware of it) benefited from the medical equipment supplied by American citizens. 